This PDF is a selection from a published volume from the National Bureau of Economic Research

Volume Title: Innovation Policy and the Economy, Volume 3

Volume Author/Editor: Adam B. Jaffe, Josh Lerner and Scott Stern, editors

Volume Publisher: MIT Press

Volume ISBN: 0-262-10100-9

Volume URL: http://www.nber.org/books/jaff03-1

Conference Date: April 16, 2002

Publication Date: January 2003

Title: The Global Innovation Divide

Author: Jeffrey Sachs

URL: http://www.nber.org/chapters/c10795 


\title{
The Global Innovation Divide
}

\author{
Jeffrey Sachs, The Earth Institute at Columbia University, and NBER
}

\section{Executive Summary}

Until very recently, science was not considered a core part of development strategy, especially in the case of the poorest countries. While this misconception is changing, as it changes, it is becoming clear that there is not enough of the critically needed science base to solve a lot of the development problems in the poorest countries. This chapter highlights the causes of this divide as well as steps that can be taken to promote a technological upgrading in lowincome countries, whether by the diffusion of technologies from abroad, or by the development of innovative technologies at home.

\section{Introduction}

My subject here is the nature of innovation systems in poor countries or, more particularly, the lack of such systems, and why innovation and technological advance do not take place at a vigorous rate in large parts of the developing world. I'm going to identify some hypotheses and research issues to be pursued, very much hoping that the research group at the NBER can take on some of the challenges. I think that the challenges of economic development are not going to be addressed properly until we better integrate issues of science and technology into the basic economic development strategies of low-income countries.

Until very recently, science was not considered a core part of development strategy, especially in the case of the poorest countries. Science and technology policy is hardly mentioned in the "Washington Consensus" approach to market reforms of the past generation championed by the Bretton Woods institutions. The World Bank went for many years without a science advisor, and for even longer without much work on science and technology policy. In general, science has been considered to be something for rich countries, while poor countries were supposed 
to focus on good governance, market reforms, and so forth. I think that this idea is changing very fast. But as it changes, we're discovering that there isn't enough of the critically needed science base to solve a lot of the development problems in the poorest countries. We have to think through why that is. Is the problem simply one of markets not working well enough, e.g. the lack of intellectual property rights protection or venture capital financing, or are their other key barriers?

\section{Global Divisions in Innovation and Technological Advance}

The right starting point for research is the incredible divide in the world between the technology innovators and the noninnovators, a division which is considerably starker than the global divisions of income. If you look at almost any indicator of commercialized technological innovation - and, of course, the patents are the easiest ones to look at-the gaps between rich and poor are startling, even compared to the gaps in income. For example, if we consider the country of origin of U.S. utility patents (determined by the country of origin of the lead inventor on each utility patent), the top ten innovating countries account for around $94 \%$ of all of the patents taken out in the U.S. in the year 2000, yet these countries have a combined population of only around $14 \%$ of the world's population. It's roughly a 96-fold higher ratio of patents per capita in the top ten countries than in the rest of the world ( $94 / 14$ divided by $6 / 86)$.

If we look at the bottom 128 countries (with population of at least 1 million) on the list ranked by total patents, each of those countries has fewer than 150 patents. Those countries have $63 \%$ of the world's population, but only 1174 patents in the year 2000 , or just $0.75 \%$ of all the patents taken out in the U.S. that year. There are several dozen countries with zero patents associated with them. Excluding South Africa, sub-Saharan Africa has had 1 to 3 patents in total in recent years, for roughly 600 million people. South Africa has had a few dozen patents per year; in the year 2000, Nigeria had 2, Kenya 1, and the rest none. So here is an entire continent with essentially no commercialized activity taking place in the U.S. If you look at other international patent data, at the WIPO data or the European Union, you'll find the same phenomenon. The issue is not specific to patents taken out in the U.S.

Many people, including myself, have made a rough three-way differentiation of the world for analytical purposes. First, there are roughly 1 billion people in countries enjoying endogenous growth, in which 
innovative activity takes place on a significant scale, and patented products and technologies are produced and sold domestically and on world markets. Thus, about one-sixth of the world's population live in countries that can fairly be described by the models of endogenous growth. The countries are sometimes termed the "core" economies, in the long-standing tradition of core-periphery models.

The second major group of countries are the technological diffusers, which, within a span of five to twenty years, absorb new technologies developed in the endogenous growth countries. Diffusion typically occurs in at least three ways. First, local firms buy high-tech capital goods to operate with increasingly advanced production processes, and typically to produce an increasingly sophisticated range of goods. Second, these countries are hosts for foreign direct investment (FDI) in manufactures and high-tech services (as opposed to commodity extraction). Third, the consumers adopt these technologies as consumer goods, such as cell phones and personal computers for home use. Still, these countries don't display innovation themselves other than in some limited areas of retrofitting internationally imported technologies for specific local use. Not much novel technology is produced. I'd estimate the diffusers at roughly three and a half billion people, a little more than half of the world. This group includes much of China (particularly in the eastern and central provinces), a large and increasing part of India (particularly in the western and southern states), a large part of Latin America (especially Mexico, Costa Rica, and the Southern Cone of South America), some parts of eastern Europe (especially the countries that border on the European Union), and at least some of the former Soviet Union.

That leaves about one and a half billion people who are marginalized in the world economy in many ways, but strikingly in the areas of technological advance. These excluded zones include much of the Andean region in South America, almost all of sub-Saharan Africa, and large parts of Central and South Asia. Of course these countries (or regions within large countries) are not fully excluded. You'll find cell phones almost anywhere in the world right now, and similarly Internet cafes in the capital cities. Technologies do eventually diffuse almost everywhere. Still, the level of penetration of new technologies (e.g. cell phones and computers per capita), the rate of diffusion, and the extent of use of new technologies in domestic production are all extraordinarily low. Total FDI in developing countries has soared, but it is highly concentrated in 10 to 15 countries among the diffusers. The excluded 
countries receive very little FDI other than in the minerals and natural resources sectors. While commodity-based FDI brings some technology, it tends to be in enclave sectors such as oil drilling and diamond mining, with little spillover of learning or technological innovation into the rest of the economy.

\section{Public and Private Sectors in the Technological Divide}

To better understand the gaps in science and technology, we should also distinguish between two important end users. Part of science and technology, usually the focus of models of endogenous growth, ends up as commercialized technologies used within the private sector. Technological advances of this kind are embodied in goods and services produced by private firms and purchased ultimately by private consumers and businesses. Another major part of science and technology, however, does not show up mainly in the private sector, but rather in the provision of public goods. For example, advances in meteorology, climate forecasting, atmospheric chemistry, environmental management, infectious disease control, geology (e.g. plate tectonics), and innumerable other areas, are inputs into the direct provision of public goods such as longterm climate forecasting, earthquake monitoring and detection, air quality management by public agencies, public health surveillance, fisheries management, environmental protection, and the like. In these cases, the end users are exclusively, or heavily, governmental agencies and other nonmarket organizations.

We can think usefully about two kinds of inputs into technological innovation and two kinds of outputs. On the input side-by which I mean the creation of new innovations and technologies-there are both private and nonprivate actors. Innovators include private businesses, government laboratories, and not-for-profit academic institutions. Increasingly, innovations emerge from the complex interplay of all three sectors. On the output side-by which I mean the final users-there are, as just noted, both private sector users and public sector users of technological advance. Studies of national innovation systems led by Richard Nelson of Columbia University and his colleagues have put great stress on the critical interplay of all of these public and private institutions on both the input and the output side as critical drivers of overall technological innovation within an economy.

In the poor countries, it must be understood that the innovation systems are failing along all dimensions, not just the private provision of 
technologies for private use. The public provision of technologies for public goods (e.g. national monitoring of the environment for purposes of public health, food productivity, climate change mitigation and adaptation, risk mitigation from natural disasters, and the like) is almost nonexistent in dozens of the world's poorest countries. These countries have governments that are so cash-strapped that they are neither investors in science and technologies (e.g. by running national laboratories) nor end users of science and technology (e.g. by running public health services to monitor and control epidemic diseases). The absence of scientific capability in the nongovernmental sectors of the poorest countries, and the lack of purchasing power by governments in these countries, are critical elements of the technological stagnation and isolation of the world's poorest countries. The problems and limitations are not simply in the private marketplace.

This point is especially critical. Even in the very richest and most market-oriented economies, such as the U.S., the public provision and use of science and technology is critical to the overall innovation process. The U.S. public sector budget for science and technology is over $1 \%$ of GNP ( $\$ 112$ billion in budget requests by the Bush Administration for science and technology in the FY 03 budget). The public sector is a major direct provider of science and technology (e.g. the National Institutes of Health, NASA, and the Department of Defense), a major financier of innovation in the nongovernmental sector (e.g. the National Science Foundation), and certainly a major purchaser and end user of science and technology. Without NIH financing and research the U.S. pharmaceutical industry would be vastly less productive in bringing new medicines to market. Indeed the lack of such public institutions in the poorest countries is certainly a critical explanation for the overall lack of technological innovation in those countries.

\section{Some Basic Sources of the Innovation Divide}

I think that there are three deep characteristics of the innovation process which help to account for the profound gaps in it between the rich and the poor, gaps that are even wider than the vast gaps in per capita income. Yet it is one thing to mention these three characteristics, and quite another to demonstrate their roles empirically and quantitatively. That is a central challenge for future research.

First, technological innovation is an increasing-returns-to-scale process, both in the production function of new discoveries (in which new 
ideas emerge from the combination and recombination of existing ideas), and in that the incentive for investment in $R \& D$ is itself dependent on the scope of the market, since $R \& D$ represents a kind of fixed cost that must be covered by sufficient unit sales of a new product or process. Because of the economies of agglomeration in the production of ideas, scientists tend to congregate-in universities, in science parks, and in regions such as Silicon Valley. This makes it extremely difficult for small, impoverished countries to hold on to their own scientists, who naturally migrate to the world's centers of science and technology. Brain drain is pervasive, and has probably accelerated in the past decade with the intensification of globalization.

Second, as I've already mentioned, science and technology is partly a market-driven phenomenon. Innovation also depends importantly on government inputs and government uses of science and technology. The poorest countries are hindered not only because their markets are small-and therefore generate little demand for innovation and little hold on their national scientists who may prefer to move elsewherebut also because their governments are small and cash-strapped, and therefore unable to make the public investments also needed for vibrant innovation. I would expect to see the research and development spending by governments as a share of GNP continue to rise significantly in the next twenty-five years, with increases of perhaps another $2 \%$ of GNP in the high income countries (on top of $1 \%$ or more of GNP spent today by governments in the technological leaders). The returns to this spending will be extremely high, and much of it will have to be done by governments rather than the private sector. In very poor countries, public sector support for science and technology hardly exists and will have to be created, and donor financing will be critical.

Third, a considerable share of modern technology, in many different areas, is highly ecology-specific. This means that technologies appropriate for one ecological setting, say the temperate zones of the U.S., may have little direct relevance in another ecological setting, say a tropical rain forest. The diffusion of technology from the advanced to the lagging countries, so important in the process of catching up, works best when the laggard shares the same ecological zone as the leader (e.g. Japan vis-à-vis Korea and coastal China) and works most poorly when the laggard is geographically isolated and in a distinct ecological zone (e.g. the tropical lowlands of sub-Saharan Africa or the tropical highlands of the Andean countries). This is a point I've often stressed, and I find more and more evidence that this is particularly true in agri- 
culture and health, but also in construction and building materials, energy sources and uses, infrastructure design, and other areas. There is tremendous ecological specificity to technological needs, and this specificity slows the diffusion of technologies across an ecological divide.

What are the implications of these three characteristics of the innovation process: scale dependence, public goods aspects of innovation, and ecological specificity? Taken together, I think these factors all help to account for the widening gaps between the rich temperate-zone economies and the impoverished countries in the tropics. These factors also help to explain why some developing countries, such as temperate or subtropical Brazil, China, and India, are achieving some measure of technological advance, while other smaller and geographically distressed countries are not.

\section{Industrial Policies for Narrowing the Technology Gap}

Without any attempt at being comprehensive in these brief overview remarks, let me mention some policy implications. A major issue facing all low-income countries is how to promote technological upgrading, whether by the diffusion of technologies from abroad, or by the innovation of technologies at home. How does a country go from being technologically excluded to being an effective diffuser of technologies from abroad? How does a country go from being a user and diffuser of technologies to being an innovator in its own right?

The most effective strategy for that purpose has been the integration of the national economy into world production. Countries that have been able to attract foreign direct investment in export-led sectors have been most successful in achieving rapid technological upgrading. Poor countries that establish themselves as bases of operation for worldclass technology leaders have enjoyed a rapid upgrading of technological potential. Notable cases include Malaysia, Costa Rica, Israel, and coastal China, all of which have been successful in encouraging leading multinational firms in electronics and information technology to establish a base of operations in their national economies. These firms use these bases of operations not mainly to serve the small domestic market, but as low-cost manufacturing sites for worldwide production and distribution of products.

A typical profile for an excluded country would find $70 \%$ of the economy in the rural sector. The exports would be $95 \%$ natural-resourcebased, heavily in agriculture and mining. Ten to fifteen percent of the 
population would live in urban areas, which tend to be administrative capitals, not economic centers, and certainly not export centers. At best, these cities supply financial and port services to the rural area, with little urban-based manufacturing for world markets. At least a billion people live in countries with such a profile.

So how would such a country become an active participant in global manufactures? Basically, it would aim to make its urban areas, especially its coastal urban areas, work as bases for globalized production. Almost all of the success stories of hooking into high technology have occurred through humble maquiladora-type beginnings, whether in Mexico or in export processing zones in coastal port cities around the world. That has almost always been the first step in moving beyond the natural resource base. One of the main problems with this path of progress is that it may be disappearing, as a result of innovation itself. There is a tremendous difference between 25 years ago and now in the proportions of people who potentially can be employed in maquiladora-type operations, because the low-skilled jobs in export zones (such as attaching electronics components to motherboards, or cutting and stitching fabrics) are being replaced by advanced machinery.

Let me also mention the next step, moving from diffusion to innovation. By my count, only a few developing countries have emerged in the past generation as innovators in their own right. We have Israel, a country that benefited from deep intellectual, financial, and familial connections with the high-tech countries. We have Korea and Taiwan, which are important cases of having gone from almost no innovation 30 years ago to quite significant rates of innovation today. Adam Jaffe's study on technological diffusion into Korea and Taiwan is the most important recent study of how those economies learned from the technological leaders. We have additional cases in Ireland, Singapore, Hong Kong, and (increasingly) coastal China.

The emergence of countries as innovators has typically required a period of intensive knowledge transfer through the importation of capital goods from the leaders, and through the processes of FDI, joint ventures, strategic alliances, and original equipment manufacturing (OEM) relationships. In addition, and somewhat more controversially, I believe that the emergence as an innovator has also required a strategic industrial policy aimed at achieving high levels of technological excellence and innovation capacity.

This kind of self-conscious drive towards scientific and technological capacity began in Israel at least 75 years ago, even before the state 
emerged, as universities were established during the period of British mandatory rule in Palestine. In the early 1970s, Taiwan and Korea became interested in science and technology as a core part of development strategy. In a rather self-conscious way, policymakers decided "We're going to need to move beyond garments, and get into electronics and other leading sectors." It was a 30-year national effort to do that, with heavy investments of government funds and political capital. Those investments now seem to be paying off with a high social and economic return, as Korea and Taiwan now benefit from their technological excellence.

Thus, there are very few countries that were low innovators a generation ago and are high innovators now, but a few did make it. The main point I would make is that markets played an important role, but so too did conscious industrial policy. In my view, promotion of a knowledge economy or innovation-based economy is not only a market phenomenon, but also a process of industrial policy and government investments in science, technology, and higher education.

\section{Science and Technology and the Excluded Poor}

Finally, I'd like to take up the question of how the international community can best support the science and technology needs of the excluded poorest of the poor. What can be done about the countries trapped by extreme poverty, geographical isolation, and ecological distress? There are four points that I want to mention briefly.

First, under any conditions, the poorest of the poor need much greater financial assistance from donors, in the form of grants, in order to meet the basic needs of health and education, and thereby to break the vicious circle of poverty, disease, illiteracy, environmental degradation, and more poverty. The Report of the WHO Commission on Macroeconomics and Health, which I chaired, stated that the rich countries should be contributing about $0.1 \%$ of GNP, or $\$ 27$ billion per year (as of 2007) to meet the urgent disease control needs of the world's poorest countries. Additional sums will be needed to meet basic needs in education, water and sanitation, energy, and environmental infrastructure.

Second, and more specifically in the science and technology realm, the international donors could support much greater efforts on the scientific issues facing developing countries in health, environment, agriculture, energy, and other areas, particularly those in which the poorest of the poor face distinctive ecological challenges. The WHO 
Commission found that the "diseases of the poor," those conditions that hit the poor countries with a highly disproportionate burden because of ecology (e.g. malaria) or living conditions (e.g. tuberculosis), tend to be dramatically underfunded in biomedical research and development. The Commission recommended a donor-supported effort of around $\$ 3$. billion per year to address these research and development needs. In addition, new financial mechanisms-such a precommitment by donors to buy new technologies such as vaccines against AIDS, malaria, and TB-could be used to add powerful private-market incentives to the direct donor support.

In addition to health, there are dramatically low levels of funding in many other critical areas of science. The Consultative Group on International Agricultural Research-(CGIAR), for example, which is the world's preeminent network of public-sector research institutes in tropical agriculture, is currently supported at the level of $\$ 350$ million a year for all the institutes combined. This sum is less than half of Monsanto's recent $R \& D$ budget in recent years. So a single (albeit leading) company has an R\&D budget more than twice that of the whole global tropical agricultural research network.

Third, there is an opportunity to rethink the intellectual property rights (IPR) regime of the world trading system vis-à-vis the world's poorest countries. In the Uruguay Round negotiation, the international pharmaceutical industry pushed very hard for universal patent protection without considering the implications for the poorest countries. There is little doubt that the new IPR arrangements can make it more difficult for consumers in the poorest countries to access key technologies, as we've seen vividly in the case of essential medicines. The countries negotiating the new Doha round are already committed to reexamining the IPR issue in light of public health priorities, and they are wise to do so. It also may well be the case that the tightening of IPRs may slow the diffusion of technology to the world's poorest countries that has traditionally come through copying and reverse engineering. Those hallowed pathways of technological diffusion are increasingly being slowed, and the effects on the poorest countries may be severe. This is an area for close observation, policy attention, and continuing research.

Fourth, we need to examine new and more dynamic approaches to technology transfer from rich to poor countries. It is amazing how many international treaties and declarations have identified technology transfer to be a goal of the international system. Yet there is very 
little operational follow-through. What kind of programs can foster technology transfer? How can they best be monitored? It's considered a life-and-death issue by at least some poor countries, and a matter of neglect by the rich countries. The poor countries are asking whether rich countries could start taking seriously some of the long-standing international commitments in this area, but so far they have not heard any response. 